\title{
Complexity in science policy
}

\author{
For those interested in what makes the world of science and technology tick, \\ and in its links with business and wealth creation, there are intellectually \\ challenging jobs to be had in science policy and administration.
}

$\mathrm{K}$ nowledge-driven economy, sustainable development, the post-genomic ministerial lips and can seem vague and uninspiring. But that view would be a mistake, as these are the phrases that reveal the philosophy guiding how the billions - roughly $\mathfrak{E} 6.5$ billion in 1998/99 across all government departments and agencies - of our money are spent on science, engineering and technology each year. And they are the words describing today's world of employment.

Between political philosophy and its reification in grant allocation, research programme or government initiative there is a long and complex process during which the principles of UK science policy are set out by officials and administrators at the Office of Science and Technology (OST) in the Department of Trade and Industry (DTI), by the research councils and by other government departments. At institutions such as the European Commission, yet more officials develop Europeanwide policies that reflect the political aims of elected governments.

These are the people who grease the wheels of active research. They might be

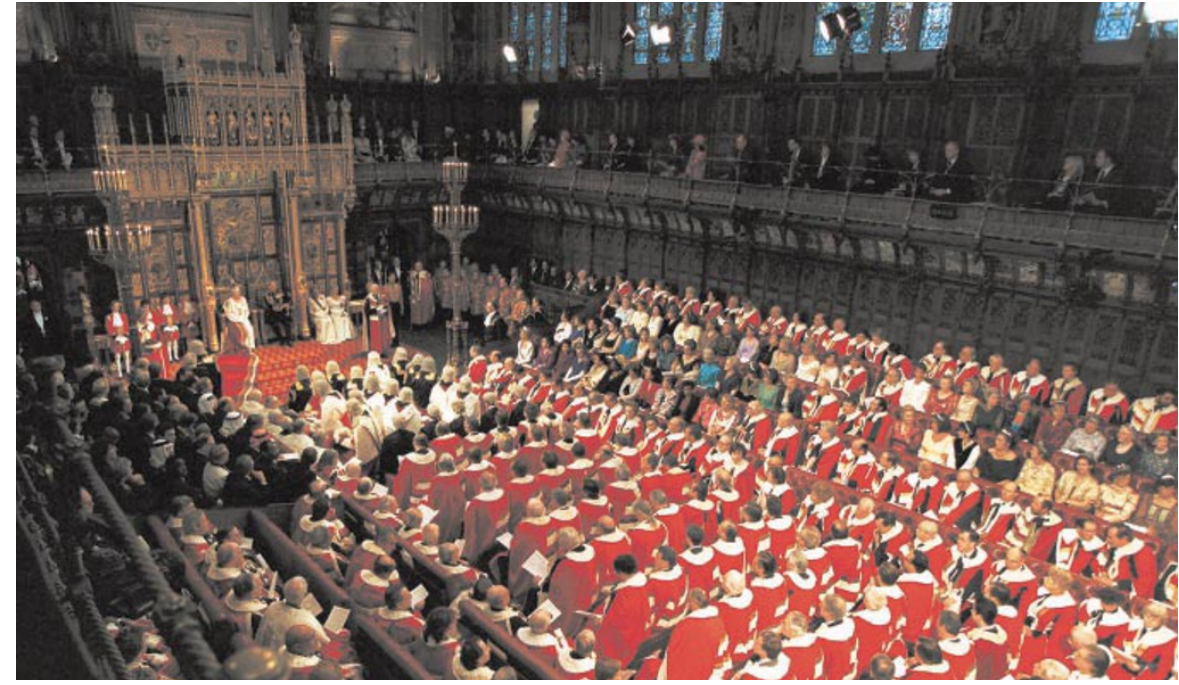

The might of democracy: but parliamentary decisions are made only after much detailed policy work.

scientific administrators dealing with the nuts and bolts of peer review, policy-makers deciding on research council strategies or negotiating Britain's position in international research programmes, or civil servants providing input to briefings for ministers on subjects ranging from radioactive waste disposal to genetically modified organisms.

\section{The route to policy-making}

Although many officials developing science policy have an education in science at least

A tale of two policy-makers. 1. From a research council

"I wasn't disillusioned with research," says David Lynn, director of planning and

communication at the Natural

Environment Research Council (NERC). "But I couldn't see what the wider benefits were of $\mathrm{my}$ work." Although the mechanism of involvement is different, he now finds the world of science policy keeps him in contact with science and gives him the broad picture he craved.

For his PhD Lynn focused on remote sensing, often called Earth observation, using NERC's aircraft. His first contact with those he calls the "men in the grey suits" came when he presented data he had collected aboard NERC's aircraft to the research council's staff. (Many of Lynn's senior staff are women so the grey suits are no longer worn by men alone.) After completing his PhD Lynn applied for a job in science administration at NERC, developing remote-sensing projects. "For the first year or so I missed active research," he says, "but l'm glad I made the choice I did."

After three and a half years with NERC, Lynn was offered a secondment that enabled him to switch from science administration to policy-making. "I see policy work as data gathering, analysis and direction setting, whereas science administration is more handle turning of the process of grant applications and peer review."

Lynn returned to NERC two and a half years later and worked on charging and access policy for NERC's huge national data archives. There followed some time in the corporate affairs unit, where he became increasing interested in the European and political dimensions of policy development owing to involvement with the European Union and Parliament. The liaison involved explaining how NERC-funded science contributed to significant public issues, such as decommissioning offshore structures or radioactive waste disposal. The information might be presented to a parliamentary select committee inquiry or as a government answer to a parliamentary question.

Then six years ago Lynn took up another secondment, this time at the science and technology secretariat of the Cabinet Office. "That was a tremendous experience at the heart of government," says Lynn. "I saw how scientific advice is applied across Whitehall... Information is needed quickly on live issues."

Now back at the NERC as director of planning and communication, Lynn's responsibilities include liaising with parliamentary select committees and responding to parliamentary questions through the Office of Science and Technology, strategic planning, and monitoring and evaluating the impact of NERC-funded science. The last of these responsibilities, says Lynn, is "an enormous exercise", which gives feedback to government about how effectively public money is being spent.

It is not essential to have a science background for science policy work, says Lynn, but it can be very useful. When he is recruiting he looks for an ability to synthesize large amounts of information. "Analytic ability, a questioning approach and communication are also important," he says. 
to bachelor level, others do not. Others may be eminent scientists or full professors who have switched to policy-making late in their careers. Take David Southwood who was head of the physics and astronomy department of Imperial College, London, and is now responsible for formulation of the European Space Agency's Earthobservation policy. Southwood headed efforts to develop a case that in June this year convinced ministers from the 15 member states of the agency to set aside 600 million euros (a little under $£ 400$ million) for monitoring Earth's resources from space.

Southwood's interest in policy started 20 years ago when he needed money for his own expensive space-based research. Working in such a pricey field drove home the message that you need to convince government and policy-makers that their money should be spent on your project and that your own research cannot be seen in isolation.

To the aspiring science policy expert or administrator, whether as a career civil servant or as someone working at a research council, curiosity about the machinery of government is essential. The process is both top down, from the executive - the government - and bottom up, from bodies such as the research councils and universities who spend the money. Both at the political level - from prime minister, chancellor and secretaries of state - and in the supporting public service sectors, the task of developing policy is multilayered, iterative and distinctly nonlinear. To coin a scientific analogy, policies are the emergent property of a seemingly chaotic system.

For a rudimentary sense of the complex- ities of the UK science, engineering and technology (SET) base it is worth studying the SET statistics published annually by the OST. The trends and spending patterns give information about where researchers are needed in industry and the public sector.

The main set of statistics is a rough breakdown of the government's SET spend, which amounted to $\mathfrak{E} 6.8$ billion in $1998 / 99$. Government decided what this spend should be during its comprehensive spending review (CSR), published in 1998. The CSR took two years to prepare and it is a blueprint for the spending during the final three years of the government's term in office. It is the vehicle that carries government policy into every area of public expenditure.

\section{The science budget}

As an illustration of how the worlds of officialdom and politics come together to determine allocation of public funds, take one strand of the SET spend - the science budget. This is the money that the research councils and the Royal Society spend, which in turn is divided between individual scientists and research groups. In the CSR, the science budget received an increase of $\mathfrak{E} 1.1$ billion ( 15 per cent in real terms) over three years, taking it to $£ 1.66$ billion annually by 2002. People at every level hold information that contributes to the decisions about how to split the money. At the sharp end of science, in the universities and research councils, trends in research emerge. When assessing grant applications, scientists and administrators spot at an early stage something such as, for example, the transition from gene hunting to research establishing gene function. Such

\begin{tabular}{|c|c|c|}
\hline $\begin{array}{l}\text { The European Union's } \\
\text { Framework programme of } \\
\text { research is funded jointly by all } \\
\text { member states. It is intended to } \\
\text { promote cross-border } \\
\text { collaboration and links between } \\
\text { industry and academic } \\
\text { institutions. The idea is that this } \\
\text { research should be in areas that } \\
\text { cannot be undertaken by one } \\
\text { nation alone. } \\
\text { David Coates from the } \\
\text { transdepartmental science and } \\
\text { technology group of the Office of } \\
\text { Science and Technology (OST) is } \\
\text { one of the officials who spend } \\
\text { their time thinking about and } \\
\text { negotiating Britain's position in } \\
\text { the Framework programmes. His } \\
\text { area of responsibility, which } \\
\text { involves both project } \\
\text { management and policy-making, } \\
\text { is biotechnology. }\end{array}$ & $\begin{array}{l}\text { Currently, Coates is } \\
\text { managing the wind up of the } \\
\text { fourth Framework programme } \\
\text { (FP4), which ran until 1998, and } \\
\text { the early calls for proposals in } \\
\text { the fifth Framework programme } \\
\text { (FP5), which will run from } 1999 \\
\text { to 2002. It will cost European tax } \\
\text { payers a little over £10 billion. At } \\
\text { the same time, he is preparing } \\
\text { for negotiations on FP6, the } \\
\text { follow-on research programme } \\
\text { to FP5. He is setting up the } \\
\text { mechanisms for initial } \\
\text { consultations with, among } \\
\text { others, industry, unions, } \\
\text { government departments and the } \\
\text { committee of vice chancellors } \\
\text { and principles. These } \\
\text { consultations will inform the UK } \\
\text { policy position for FP6. } \\
\text { Coates says his job depends } \\
\text { on an awareness of the political }\end{array}$ & $\begin{array}{l}\text { environment, as well as on } \\
\text { presentation, communication } \\
\text { and negotiating skills and an } \\
\text { ability to synthesize large } \\
\text { amounts of data from different } \\
\text { sources. } \\
\text { After completing a PhD in } \\
\text { microbiology, Coates joined the } \\
\text { commercial side of the chemical } \\
\text { industry and studied for an MBA. } \\
\text { He learned negotiation and } \\
\text { presentation from the } \\
\text { commercial world, then joined } \\
\text { NERC and was exposed to policy, } \\
\text { and was then seconded to the } \\
\text { OST. Of science policy jobs in } \\
\text { general, Coates says that "fif you } \\
\text { are not comfortable with } \\
\text { short deadlines and } \\
\text { manipulating lots of } \\
\text { information from lots of } \\
\text { sources then you will } \\
\text { struggle"y. }\end{array}$ \\
\hline
\end{tabular}

information feeds upwards through the research councils and outwards to the OST and other government departments, being synthesized with information from other disciplines by officials with ever wider briefs.

\section{Knowledge-driven economy}

At the other end of the scale, where the executive has the responsibility for planning for the country's future economic well being, politicians aspire to seeing the much vaunted "big picture". Hence the prime minister will give a speech pointing out that Britain no longer has an empire, has few national resources and that its future depends on the knowledge and creativity of individuals — the so-called knowledgedriven economy. Recognition of the significance of the knowledge-driven economy then feeds into government policy, and the choices made in the CSR, from industrial and economic policy to science policy.

Take, for example, the decision to increase the budget of the Biotechnology and Biological Sciences Research Council. "This was really saying that biological sciences are going to be extremely important in the next century, in terms of underpinning both science and industries of the future...part of the CSR was an extra allocation for exploiting genome valley," says Lord Sainsbury, the science minister, in an interview with Nature. Sainsbury, who was responsible for allocating the science budget, says that "we have an outstanding science base and we see this as being an important national asset in terms of the knowledge-driven economy". Hence the additional $\mathfrak{E} 1.1$ billion for science.

What does a phrase that can attract such large amounts of money mean? "To me it is a description of what is happening in the economy," says Sainsbury. "At its simplest, knowledge-driven means that the physical content of products and services in the new industries is becoming less and less. Added value, attributed through intellectual processes, is becoming greater and greater. Take Microsoft, it has virtually no physical assets, but it has a huge capitalization based on its knowledge."

There are, argues Sainsbury, numerous examples of where the knowledge derived from the science and engineering base are adding value to products. "It is the ability to manage the knowledge that creates these products and services which gives a competitive advantage, rather than managing physical engineering," says Sainsbury.

\section{Filtering of advice}

How and where do the policies and the world of active research funded by the research councils fit into these wider issues? The two come together when the science minister sits down with John Taylor, the director general of the research councils, to apportion the science budget. Taylor will 
have listened to the priorities expressed by the chief executive officers of the research councils who, in turn, are briefed by their staffs. Both science minister and director general have access to the findings of the science and engineering base group of the OST.

As back up during this process, the science minister can draw on the policy summaries and briefing papers of the DTI's civil servants. The minister is also advised by the chief scientific adviser who has an office in both the DTI and the Cabinet Office and who is responsible directly to the prime minister. From his post in the Cabinet Office, the chief scientific advisor has a view of the science efforts across Whitehall. Both chief scientific advisor and science minister are supported by the transdepartmental science and technology group of the OST.

It is through this mesh of policy groups that the advice filters that leads to an allocation of funding among the research councils. "Dividing the science budget was a difficult decision," says Sainsbury. Once the alloca- tions are made, the research councils decide internally how to spend the money, but broad strategies laid down at the time of the funding allocation guide the decisions.

So much for the science budget. Science policy is also important for industry. The location of the science minister's office within the DTI reflects an article of faith both for this and the previous government that Britain's economic success rests on there being more commercial exploitation of the science base and closer links with industry.

The complex and iterative process of deciding the science budget applies at all levels in each of the elements of the UK's SET spend, including that spent to support the UK's participation in the European Union's fifth Framework programme. Preparations are now underway across government for the next CSR, which will be the Labour Party's blueprint for government spending from 2002 should it be re-elected. In short, there is plenty of work for science, engineering and technology policy-makers.

\section{Job search}

For further information about how to join the civil service fast stream, check: http://www.rasnet.co.uk/RAS/capitaras.html.

The Office of Science and Technology (OST)'s transdepartmental science and technology group, which is headed by Jo Durning, is considering making formal arrangements for taking secondees from universities, although she says that "this is currently only an idea". Further information on science policy can be found at http://www.hmtreasury.gov.uk/ $\mathrm{pub} / \mathrm{html} / \mathrm{csr} / 401101 . \mathrm{htm}$ and

http://www.dti.gov.uk/ost.

For general jobs in science policy, check the classified adverts of Nature and newspapers such as The Guardian (website addresses on listed on $p$. A3).

The OST's SET statistics are published by The Stationery Office and can be accessed online at http://www.dti.gov.uk/ost/SETstats98.

\section{A view from the employers' side of the fence}

\section{Results from a recent survey of large employers indicate the growth areas of employment and the level of competition that applicants should expect to face. The findings also highlight the skills that employers are seeking.}

A graduate's most important skills, say employers, are interpersonal skills, motivation and enthusiasm, and team working ability - in that order. The skills most often lacking but desirable, they say, are leadership ability and business awareness.

These findings emerge in a survey of large employers, like Logica and AstraZeneca, which are members of the Association of Graduate Recruiters (AGR). The strongest anticipated growth areas for employment are the public sector (19.4 per cent), areas of manufacturing (19 per cent), business services including finance and accountancy (18.5 per cent), and electrical and electronic engineering (13 per cent). The median predicted starting salary for undergraduates in 1999 was $£ 17,400$.

AGR is a professional association with a membership of about 600 mainly large company and public sector employers. Twice yearly, the Institute of Employment Studies undertakes a salaries and vacancies survey for the association. Some 263 firms participated in the last survey and 23 of these were interviewed to explore specific issues in depth in a qualitative fashion.

\section{Competition for jobs}

The survey shows that applicants face tough competition for jobs. On average, 67.9 people applied per vacancy, 14.8 people were short listed per job and 8.4 were interviewed. Although these may be daunting numbers for applicants, they imply a seemingly healthy state of affairs from the employers' perspective. Nevertheless, some vacancies remained unfilled from 1998 and

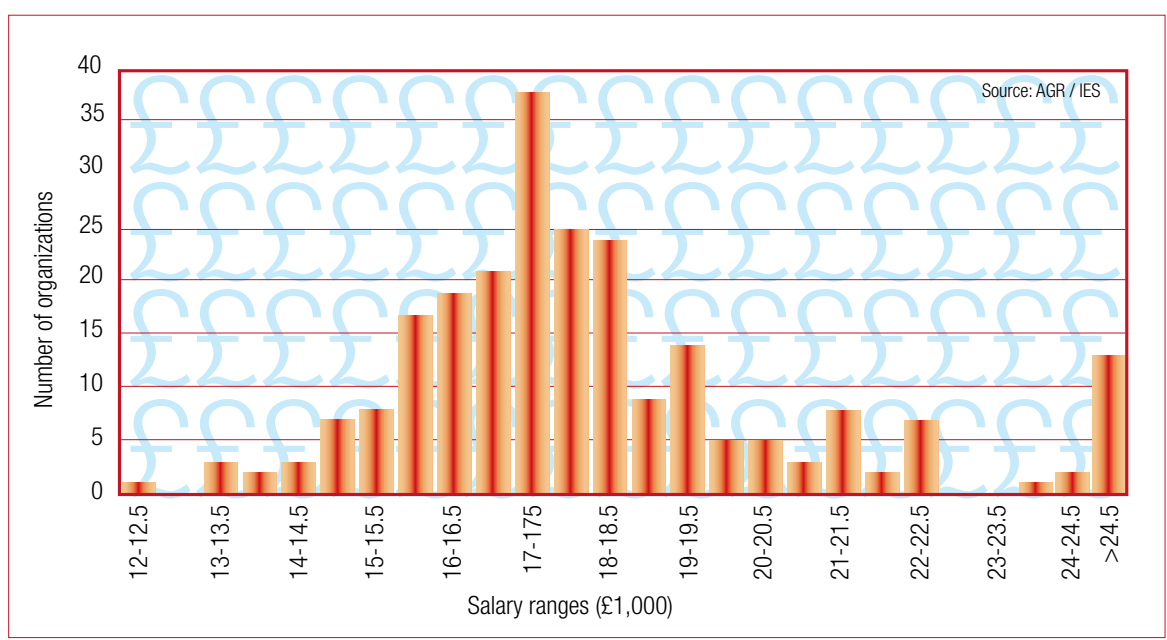

Forecast of graduate starting salaries for 1999. 